\title{
COMPRA E VENDA NO CÓDIGO VISIGÓTICO
}

\author{
SALES AGREEMENTS IN THE VISIGOTHIC CODE
}

\section{Patrícia Cândido Alves Ferreira*}

Resumo:

Este artigo analisa o contrato de compra e venda no Código Visigótico, o monumento legislativo mais notável elaborado pelos visigodos, promulgado em 654 por Recesvindo. À luz do referido Código, o estudo examina o desenvolvimento da compra e venda com base em suas características mais importantes (por exemplo, preço, transferência de domínio, escritura, prova testemunhal, fiança, arras e proibição de venda de coisa alheia ou em litígio).

Palavras-chave: Compra e venda. Código Visigótico.

\begin{abstract}
:
This paper analyzes the sales agreements in the Visigothic Code, the most remarkable monument of legislation which ever emanated from visigothic people, promulgated in 654 by Recesvintus. This study observes the evolution of the visigothic purchase and sale, based on its most important features (for example, price, property, surety, pledge, those who sell the property of others or the property whose ownership is in dispute).
\end{abstract}

Keywords: Sales agreements. Visigothic Code.

1. Compra e venda no Código Visigótico: considerações gerais

Promulgado por Recesvindo no ano de 654, o Código Visigótico, ${ }^{1}$ a compilação mais relevante de leis visigodas, de cunho territorial tanto para godos

Doutoranda em Direito Civil e Mestra pela Faculdade de Direito da Universidade de São Paulo (Largo de São Francisco). Bacharela em Direito pela Universidade Federal de Goiás (UFG).

1 O Código Visigótico, também denominado Lex Visigothorum Recesvindiana, Liber Iudiciorum, Liber Iudicum, Forum Iudicum ou Fuero Juzgo, foi promulgado em 654, por Recesvindo. Além da versão recesvindiana, houve a versão ervigiana (681), de caráter oficial (devida ao rei Ervígio), e a vulgata, não oficial (de iniciativa particular de juristas e práticos anônimos do direito). O Código Visigótico é composto de 12 livros, divididos em títulos, que, por sua vez, estão subdivididos em leis, situando-se a compra e venda no Livro V, Título IV. 
quanto para hispano-romanos, ${ }^{2}$ dispõe sobre a compra e venda em seu Livro V (De Transactionibus), Título IV (De Commutationibus et Venditionibus). ${ }^{3}$

No tocante ao conteúdo, há uma conhecida divergência doutrinária quanto a ser a compra e venda visigótica fruto da persistência dos costumes germânicos ou resultado do esfacelamento do direito romano ocidental.

\section{Escritura e testemunhas}

A escritura lavrada pelos notários (LV 7,5,9) conferia proteção legal ao negócio jurídico e ao próprio instrumento negocial, com punição da falsidade documental (falsariis scripturarum, LV 7,5). Há vestígios do emprego da escritura até mesmo nas áreas rurais (PETIT, 1983, p. 169).

Em alguns negócios jurídicos, o Código Visigótico prescreve a forma escrita e solene como requisito essencial de sua validade, a exemplo da doação mortis causa entre cônjuges (LV 5,2,7). Em outros negócios, ainda que a forma escrita não seja essencial para sua validade, a lei dispõe sobre as vantagens processuais da utilização da escritura, como na hipótese de penhor dado em garantia (LV 5,6,3).

$\mathrm{Na}$ compra e venda, a escritura, mesmo não sendo essencial para a validade do negócio jurídico, parece ser a forma preferencial no Código de Recesvindo (especialmente, nas negociações de maior vulto). Entretanto, a compra e venda celebrada verbalmente também é dotada de validade, desde que firmada perante testemunhas (LV $5,4,3)$.

Acenando para a possibilidade de previsão de cláusula penal (LEVY, 1956, p. 131), o Código Visigótico sujeita à pena o outorgante que se opor a pacto lavrado por escritura legítima que se obrigou a respeitar, a menos que tenha agido por medo ou força (LV 2,5,5). Esta última exceção, o agir por medo ou força, é robustecida pela disposição que dá por nula a compra e venda realizada sob coação (Ne valeat violenter facta venditio,

2 Sobre o problema da pessoalidade $\mathrm{x}$ territorialidade no direito visigótico: AZEVEDO, Luiz Carlos de. O direito visigótico. Revista da Faculdade de Direito da Universidade de São Paulo, São Paulo, v. 96, p. 3-16, jan./dez. 2001. p. 3-16; COSTA, Mário Júlio de Almeida. História do direito português. 4. ed. Coimbra: Almedina, 2010. p. 147-152; SILVA, Nuno J. Espinosa Gomes da. História do direito português: Fontes do direito. 4. ed. Lisboa: Calouste Gulbenkian, 2006. p. 68-89; GARCÍA-GALLO DE DIEGO, Alfonso. Nacionalidad y territorialidad del Derecho en la época visigoda. Anuario de Historia del Derecho Español (AHDE), Madrid, n. 13, p. 168-264, 1936-1941. p. 168-264; ZEUMER, Karl. Historia de la legislación visigoda. Traducción del alemán por Carlos Clavería. Barcelona: Facultad de Derecho de la Universidad de Barcelona, 1944.

3 Para fins deste trabalho, foi utilizada a seguinte fonte: ESPANHA. Fuero juzgo en latín y castellano: cotejado con los mas antiguos y preciosos códices por La Real Academia Española. Madrid: Ibarra, Impresor de Cámara de S. M., 1815. 
LV 5,4,3). ${ }^{4}$ Tal coação se relaciona à ameaça de morte ou restrição de liberdade (vis ou metus, LV 2,5,9), independentemente de realizar-se o negócio por forma escrita ou verbal perante testemunhas.

Acredita-se que o modelo de compra e venda com efeito translativo imediato, presente no direito visigodo, desenvolveu-se graças ao maior emprego da escritura, a qual era um atestado do exaurimento do contrato, mediante a entrega do preço e a transferência instantânea da coisa. A relevância dada ao instrumento escrito na compra e venda era nítida nas fontes da época, as quais, contudo, não detalhavam a correlação entre o ato escrito e a entrega do preço (MERÊA, 1948, p. 73).

\section{Efeito translativo imediato}

Com o advento do séc. IV, a compra e venda assume um novo perfil, trilhando uma mudança que se esboçava desde a legislação constantiniana. Nesse ínterim, deixa ser tratada como simples contrato consensual clássico, o qual acarreta obrigações e desencadeia um ato translativo de propriedade (mancipatio, traditio), passando a ser tida como ato dotado de efeito translativo imediato (MERÊA, 1948, p. 71-72).

Em um necessário cotejo, no direito romano clássico, o mútuo consenso bastava para gerar obrigações para ambos os contraentes da compra e venda; porém, no direito helenístico, a compra e venda requeria a entrega do preço para ser perfeita e não trazia obrigações para os contraentes enquanto não fosse dado o preço. Este, o preço, uma vez entregue ao vendedor, atribuía ao comprador uma propriedade revestida de alguma eficácia sobre a coisa (MERÊA, 1952, p. 50).

Merêa (1948, p. 73) adverte que a compra e venda com efeito translativo imediato existia no direito germânico, mas também era encontrada no direito de outros povos. É precipitado, portanto, dizer que a compra e venda visigótica refletia características costumeiras herdadas apenas do direito germânico, assim como não se pode afirmar que o desenvolvimento desse contrato no Baixo Império se deve à influência germânica. Tornase mais fácil acreditar em um contorno oriental (helenístico), porém, ainda assim, não é fácil divisar essa moldura.

Na realidade, os modelos clássicos não eram acessíveis a toda população, de sorte que essa compra e venda instantânea e sintética (Bargeschäft), à moda primitiva, assemelhava-se mais a uma permuta automática do objeto pelo preço, ato este que, por si

$4 \quad$ Antonio Padoa Schioppa diz que certas leis de Chindasvindo e de Recesvindo têm a marca religiosa e eclesiástica, refletindo as ideias de Isidoro, bispo de Sevilla, e permitindo, por exemplo, a anulação de um contrato celebrado sob temor ao rei (História do direito na Europa: da Idade Média à Idade Contemporânea. São Paulo: WMF Martins Fontes, 2014. p. 31). 
só, era suficiente para esgotar os efeitos do negócio - pelo menos, os efeitos primários e essenciais (MEREAA, 1948, p. 73).

O doutrinador português atenta para uma constatação: há quem ensine que, no direito romano, a propriedade não se transferia para o comprador enquanto o vendedor não recebesse o preço (ainda que houvesse mancipatio ou traditio), ressalvada a hipótese de o comprador dar garantia equivalente ou o vendedor demonstrar que acreditava no comprador. Entretanto, esse ensinamento seria questionável, porque, independentemente da discussão sobre o direito clássico, o direito pós-clássico determinava o pagamento do preço para a transferência da propriedade. Longe de ser uma nova e rígida dogmática para a compra e venda, são novas tendências, ainda escoradas nos arcabouços tradicionais, dentre os quais o Breviário de Alarico, que acolhia a doutrina clássica dos contratos por meio da Epitome Gai. É nesse contexto que deve ser examinado o Código Euriciano, o qual não somente possui muito da índole romana, como tem a maioria das suas disposições sobre compra e venda transportadas para a Antiqua do Código Visigótico (MERÊA, 1948, p. 73-74).

\subsection{Entrega do preço e transferência do domínio}

É conhecido o embate entre romanistas e germanistas para conformar o direito visigótico às respectivas escolas que integram, o que alcança as discussões doutrinárias sobre a compra e venda.

Merêa (1948, p. 80) discorda das orientações de Gierke e Schröder, sob o argumento de que Gierke, adepto da doutrina do contrato real (Realvertrag), diz que o comprador tem de pagar o restante do preço na ocasião em que o vendedor lhe entregar a coisa; enquanto Schröder acredita que o comprador pode ter a coisa antes de pagar o restante do preço, a menos que haja uma promessa formal (wadiatio) de pagar o que falta, quando, então, o vendedor pode exigir a restituição da coisa, como era costume no direito germânico.

Todavia, Merêa (1948, p. 80-81) refuta essa exigência de promessa formal quanto à parte do preço aprazado, pois o verbo promittere, seja nas fontes romanas, seja nas fontes visigóticas, possui sentido amplo, e não meramente documental (ademais, na época, já era praxe o legislador especificar quando o ato ou negócio requeria forma especial). Portanto, em sua opinião, a venda produz efeitos desde a entrega do preço (parcial ou total).

Assim como no direito romano, o preço (praetium) na compra e venda visigótica correspondia a um valor em dinheiro (numerata pecunia), porque, do contrário, seria uma permuta, e não uma compra e venda (JUSTO, 2006, p. 53). No mais, quanto à 
origem, o preço devia ser verdadeiro e, quanto à totalidade, podia ser inteiro ou aprazado (dividido em partes).

No tocante à autenticidade do preço, por exemplo, não tem efeito para o Código Visigótico a venda de servo que é comprado com seu próprio pecúlio, pois, desconhecendo o vendedor (dono do servo) a origem do preço, não haveria venda legítima, já que o valor pago era coisa pertencente ao próprio vendedor, e não um preço verdadeiro (LV 5,4,17). Tal negócio, porém, seria válido segundo os preceitos do direito romano, obrigando-se o comprador do servo a entregar um preço verdadeiro; entretanto, é um negócio ineficaz perante o direito pós-clássico, o qual considera a entrega do preço um elemento essencial.

Note-se, também, que o Código Visigótico declarava expressamente a incapacidade dos servos para celebrar contrato (seja por escritura, seja mediante testemunhas), a menos que tivessem um mandato de seu senhor (LV 2,5,6). Caso chegassem os servos a contratar sem referido mandato, o negócio resultante seria inválido.

No caso da venda perfeita por escritura, esta seria lavrada após ou no momento da entrega do preço, pois o ato escrito representava um negócio já celebrado, o qual gerava a obrigação do vendedor de entregar a coisa (MARLASCA MARTÍNEZ, 2010, p. 97) e, uma vez efetuada a entrega do preço pactuado (elemento consensual do contrato), impedia o vendedor de impugnar a venda por insatisfação com a quantia recebida ( $\mathrm{LV} \mathrm{5,4,7).}$

A propósito, identificam-se, nesse ponto, elementos da lesão enorme (laesio enormis), que, no Código Visigótico, tanto guarda relação com o preço quanto com as causas de rescisão contratual. O Código de Eurico não admitia a rescisão da venda tão somente porque o vendedor alegou que vendeu bens a preço ínfimo. Já a legislação recesvindiana evoluiu ao conceder alguns efeitos à laesio enormis e estabelecer que, havendo celebração da compra e venda mediante fraude contra a vontade do vendedor e sendo o preço entregue menor que o preço do objeto, o comprador teria a obrigação de dar ao vendedor o dobro da diferença (FERNÁNDEZ ESPINAR, 1955, p. 359).

\subsection{Transferência de domínio sob a perspectiva das Fórmulas Visigóticas}

Cabral de Moncada (1948, p. 4-6) afirma que o Código Visigótico, principalmente no âmbito dos contratos civis, traz muito do direito romano, mas, por outro lado, tal Codex se mostra afeito aos modos derivados de aquisição do domínio (quando, então, se distancia não somente do direito romano, como também do direito germânico, assemelhando-se mais ao Código Justinianeu). $\mathrm{O}$ transferente entrega o documento escrito ao adquirente da propriedade, sendo tal escritura suficiente, por si só, 
para realizar a transferência do domínio, raciocínio este que é praticamente idêntico para a compra e venda, a doação e a troca.

Para justificar seu posicionamento, o autor busca, nas Fórmulas Visigóticas, ${ }^{5}$ uma disposição para a venda (n. 11, Venditio) e outra para a troca (n. 27, Commutatio): a primeira cuida da venda de um escravo (tradidi tibi supra memoratum servum); enquanto a segunda é omissa quanto ao objeto da troca (hoc et illude), presumindo-se que sejam móveis, isto é, prevalecendo a traditio (MONCADA, 1948, p. 6).

Na linha de entendimento de Cabral de Moncada (1948, p. 7-10), a entrega

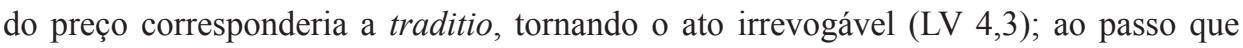
a transferência do domínio nas doações e vendas ocorreria com a entrega do título de alienação - a traditio per chartam, oriunda do direito romano e adotada no direito visigótico -, ou a entrega do preço - ainda que fossem bens imóveis, porque a prática da tradição serviria, no máximo, para bens móveis.

Dentre as Fórmulas Visigóticas, as fórmulas 11, 12 e 13 dedicam-se à compra e venda. Merece especial exame a fórmula 11, que, embora trate de venda de servo liberto pelo próprio senhor, melhor reúne os elementos constituintes do contrato de compra e venda: determinação do preço (o praetium in solidi ${ }^{6}$ numeri), descrição do objeto da compra e venda (a res, no caso, o servum) e os efeitos do contrato (a conventio obriga o vendedor a entregar a coisa - tradere,$-{ }^{7}$ e o comprador a pagar por ela - solvere).

A fórmula 11 também se refere aos vícios ocultos e à evicção no tocante ao objeto do contrato: o servo negociado deveria estar bem de saúde (non causarium), além de não ser fugitivo (non fugitivum, non vexaticium), visto haver vedação expressa à compra e venda de coisa alheia no Código Visigótico (LV 5,4,8 e 5,4,9).

Da fórmula 11, infere-se, ainda, uma concepção de propriedade e posse (e mesmo de usufruto), os quais são tratados como institutos muito próximos (habere, tenere e possidere), para não dizer fundidos ou confundidos (se não em teoria, ao menos na prática). Ainda assim, não se descarta que houvesse uma adequação do instituto à

5 "Dá-se este nome a uma coleção incompleta de modelos para redação de documentos ou escrituras públicas, formada provavelmente no reinado de Sisebuto por um notário da cidade de Córdoba, com o objetivo de facilitar o desempenho da tarefa daqueles que se dedicavam a este último ofício, oferecendo-lhes modelos para que se ajustassem na redação dos documentos de uso mais frequentes. (...) Deve-se situar, portanto, sua redação entre os anos de 615 e 620, ano este em que morreu Sisebuto." (HINOJOSA Y NAVEROS, Eduardo de. Historia general del derecho español Madrid: Tipografía de los Huérfanos, 1887. t. 1, p. 366, tradução livre).

6 Moeda constantiniana utilizada na época.

7 Há entendimento de que o uso do verbo tradere nas Fórmulas Visigóticas equivale à simples entrega da coisa, e não a um instituto autônomo, como a traditio romana, e tampouco a um requisito para tornar o contrato perfeito, de modo que o contrato se aperfeiçoaria com a entrega do preço, mas não com a entrega da coisa (CÓRCOLES OLAITZ, Edorta. El contrato de compraventa a la luz de las fórmulas visigodas. Revista Internacional de Derecho Romano, Ciudad Real, n. 1, p. 309-330, oct. 2008. p. 315). 
casuística. Ademais, a compra e venda do servo comportava reclamação ou defesa (in perpetuum vindices ac defendas). A princípio, era plena a disponibilidade da pessoa do servo, renunciando o antigo dono aos direitos sobre ele, o qual passava à propriedade do novo dono (CÓRCOLES OLAITZ, 2008, p. 315).

A fórmula 12 alude a um negócio consensual realizado sob o manto da boafé e protegido de vícios, criando um ambiente ideal para a manifestação da autonomia da vontade. Há, todavia, controvérsia sobre: (i) tratar-se de compra e venda ou de doação (caritati profiteor); (ii) serem ambos os institutos vistos com alguma similaridade pelos juristas visigodos; ou (iii) consistir em uma fórmula ampla para a venda (e não para a compra e venda propriamente dita). ${ }^{8}$

Inclina-se, aqui, para a última hipótese, qual seja, a fórmula aplica-se à venda em geral, haja vista que estão ausentes em seu texto alguns elementos essenciais do contrato visigótico de compra e venda, tais como o praetium e a tradere.

A Fórmula 13 também não especifica o preço, mas tão somente o tangencia.

Deduz-se que, no que se aplica à compra e venda, ressalvada a maior completude da fórmula 11, as fórmulas 12 e 13 não continham todos os elementos essenciais do contrato de compra e venda, o que leva a crer que ambas serviam de complemento ou eram complementadas pela legislação visigótica.

\section{Compra e venda de coisa alheia}

Era preceito geral do direito visigodo que todas as coisas podiam ser objeto de compra e venda, desde que vendidas por seu legítimo titular e ressalvados os casos com vedação expressa, a exemplo da coisa alheia.

O Código Visigótico diz expressamente que não tem validade a venda de coisa alheia ( $\mathrm{LV} 5,4,3$ ), atribuindo o crime de furto ao comprador que, agindo de má-fé, compra coisa que saiba não pertencer ao vendedor. Mais precisamente, o criminoso não é apenas quem pratica o furto, mas também aqueles que sabem e consentem quanto ao furto, bem como os receptores da coisa que saibam ser furtada (LV 7,2,7).

García-Gallo (1936, p. 209) afirma que a responsabilidade do vendedor de coisa alheia que esteja imbuído de má-fé segue a regra do direito germânico: pagar

Cabral de Moncada refere-se somente à fórmula 11 ao tratar de compra e venda, ignorando as fórmulas 12 e 13 (MONCADA, L. Cabral de. Estudos de história do direito. Coimbra: Imprensa da Universidade, 1948. v. 1. p. 6). Córcoles Olaitz cita as fórmulas 11,12 e 13 para referir-se à compra e venda, mas, à exceção da fórmula 11, reconhece que a 12 e a 13 talvez não se destinem à compra e venda em sentido estrito, e sim à venda em geral (CÓRCOLES OLAITZ, Edorta. El contrato de compraventa a la luz de las fórmulas visigodas. Revista Internacional de Derecho Romano, Ciudad Real, n. 1, p. 309-330, oct. 2008. p. 322-324). 
o dobro ao proprietário da coisa, restituir o preço ao comprador e indenizar eventuais melhorias feitas na coisa pelo comprador. (GARCÍA-GALLO DE DIEGO, 1974, p. 209).

Nos casos em que o comprador de boa-fé adquire do vendedor coisa alheia sem sabê-lo, disporá de um prazo para encontrar o vendedor e, caso não o encontre, deverá apresentar juramento, testemunhas ou fiador de que o encontrará, entregando a coisa ao verdadeiro dono e dando-lhe a metade do preço pago ( $\mathrm{LV} 7,2,8)$.

Aquele que vende coisa alheia que pense ser sua não deve o duplum ao verdadeiro dono, mas somente a coisa, ficando, em contrapartida, responsável perante o comprador em caso de evicção. Isso se dá porque o erro acerca do direito de propriedade seria mais grave do que o erro acerca da qualidade da coisa.

Em todo caso, permanece ileso o direito do verdadeiro dono da coisa, a qual, apesar de ter sido objeto de transação ilegítima, continua a lhe pertencer, sendo passível de sequela por seu titular.

Está clara, por conseguinte, a influência do direito romano no Código Visigótico quanto à proibição da compra e venda de coisa alheia (nullum domino praeiudicium comparet).

Sem dúvida, o dispositivo LV 5,4,3 é rico e interessante, visto que não se limita a proibir ou invalidar a compra e venda de coisa alheia, mas também alcança direitos ou sanções decorrentes para todos aqueles que, direta ou indiretamente, estejam envolvidos no negócio proibido ou sejam prejudicados por este.

\section{Arras}

O Código Visigótico prevê que a entrega das arras ao vendedor é suficiente para que este fique obstado de rescindir a compra e venda, mas, em contrapartida, o

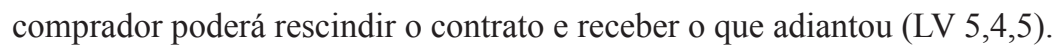

Em hipótese de enfermidade ou outra causa grave que dificulte o comprador de pagar o restante do preço no prazo combinado, ele poderá incumbir outrem de pagar em seu nome ou, se isto não for viável ou não quiser fazê-lo, poderá reaver a parte que adiantou, desistindo da compra (LV 5,4,4). Tal disposição não encontra eco nos princípios clássicos do direito romano, para os quais o comprador não se desvencilhava da obrigação ao não pagar parte do preço, motivo pelo qual se conclui que o Código Visigótico opta pela linha da lex comissoria. (MERÊA, 1948, p. 102). Nota-se, aqui, a presença do elemento volitivo em favor do comprador.

Da maneira tratada no Código Visigótico, as arras traziam consideráveis deveres contratuais para seu receptor, que, além da custódia do objeto da compra e venda, deveria, se recebesse a outra parte, entregar a coisa ou, se não recebesse essa parte restante, precisaria devolver a parte paga (LEVY, 1951, p. 153). 
Merêa (1952, p. 40-51) esclarece que a legislação visigótica não prevê a arra penitencial nos moldes dos direitos grego e egípcio, tampouco se assemelha à arra romana, de cunho mais argumentativo (o argumentum emptionis et venditionis contractae, de Gaio); logo, o Código Visigótico (LV 5,4.4) não impõe o jus paenitendi ao receptor da arra, ao passo que o comprador poderá recuperar a arra se, não reclamando a coisa no prazo, tornar sem efeito a compra e venda.

Discordando parcialmente de Merêa, D’Ors (1956, p. 215) acredita que as arras visigóticas funcionavam à semelhança das arras romanas, ou seja, um sinal confirmatório de um contrato consensual, distanciando-se das arras penitenciais do direito helenístico.

Era fato, contudo, que as arras visigóticas tinham características bastante peculiares, tanto que não passaram para o direito pós-gótico.

Otero Varela (1955, p. 192), reconhecendo essa complexidade das arras visigóticas, entende que a entrega de parte do preço confere firmeza à compra e venda. Entretanto, não obstante a mencionada "firmeza", sabe-se que o pagamento de parte do preço não era suficiente para perfazer (perfectio) o contrato de compra e venda.

$\mathrm{Na}$ hipótese de o comprador pagar uma parte do preço e deixar a outra parte por pagar (Si pars pretii data est, et pars promissa non adimpletur, LV 5,4,5), essa circunstância, exclusivamente, não desfazia o negócio. Nesse particular, D’Ors (1956, p. 216) suscita a possibilidade de tratar-se de uma compra e venda não escrita, embora a promessa quanto à parte do preço por pagar possa constar de documento especial.

Todavia, se o comprador não pagar a parte restante no prazo convencionado, deverá pagar ao vendedor seus interesses correspondentes (usurae) sobre a parte não satisfeita, o que equivale mais do que os meros juros moratórios do direito romano vulgar (MEREAA, 1948, p. 94).

Existe posicionamento doutrinário no sentido de que, se o devedor não pagasse a parte do preço no dia combinado, o vendedor deveria reclamar mediante convenção a coisa porventura na posse do comprador, solução que vem da aplicação analógica do Código Euriciano (CE 297), pois o Código Visigótico não possuía previsão específica (OTERO VARELA, 1955, p. 192-193).

Desse modo, é pacífico que o Código Visigótico não possibilitava ao vendedor a retenção das arras entregues pelo comprador quando este não cumprisse a obrigação de pagar a outra parte do preço, mas facultava ao vendedor a resolução contratual (LV 5,4,4).

Mesmo que haja um direito de crédito em favor do vendedor, tal direito não lhe faculta anular a venda por falta de pagamento do restante do preço, nem exigir, ao seu livre arbítrio, a restituição da coisa vendida. Apenas no caso de o comprador não completar o preço dentro do prazo fixado seria possível a anulação da compra e venda, 
desde que isso fosse objeto de acordo prévio entre os contraentes. Trata-se de previsão equivalente à lex commissória do direito romano, valendo, portanto, o ut res vendita reformatur, ou seja, não se restitua a coisa vendida.

\section{Fiador}

O Código Visigótico determina que ninguém compre coisa de quem não conhece se este não apresentar bom fiador ( $\operatorname{LV} 7,2,8)$.

O vendedor deveria ser idôneo (idoneus), mas, na ausência desse critério, poderia apresentar ao comprador um fiador (fideiussor), homem livre, de modo a conferir firmeza e validade à compra e venda ( $\operatorname{LV~5,4,2).~}$

Idoneidade tinha o sentido de solvência. Se pairasse dúvida sobre ser o vendedor solvente, o cumprimento da condição de apresentar seu fiador ao comprador tornava firme a compra e venda. Fiança era, assim, um instrumento a favor do comprador cauteloso, que temesse adquirir coisa, por exemplo, alheia, proibida ou litigiosa.

A falta de apresentação de fiador pelo vendedor supostamente inidôneo não acarretava a rescisão contratual. Isso porque, sendo a fiança uma condição para a celebração do negócio (e não uma obrigação do vendedor), seu não preenchimento já persuadia o comprador a sequer celebrar o contrato.

No Código Visigótico, inexiste disposição que remeta à insolvência superveniente do vendedor (que era, no início da negociação, solvente e, por isso, não teve de apresentar fiador). Por óbvio, estaria garantida pela fiança a insolvência superveniente do vendedor que, sendo inicialmente inidôneo, teve de apresentar fiador no início da negociação.

Digna de nota é a coisa em litígio (rem in contemptione) e sua relação com a solvência do vendedor, até porque a matéria de fundo do litígio costuma residir exatamente na propriedade sobre a coisa. O Código Visigótico, entretanto, na linha da legislação visigótica que o precede, proíbe a venda de coisas pendentes de litígio (LV $5,4,20)$, pois, se será preciso, vezes várias, aguardar até por coisa própria, quanto mais por coisa comum. Essa parece ser, contudo, uma posição decorrente do direito romano vulgar, uma vez que o direito germânico não possuía vedação expressa à compra e venda de coisa em litígio (FERNÁNDEZ ESPINAR, 1955, p. 356).

Assim como a coisa em litígio, o Código Visigótico pró́be a venda das coisas que demandem decisão judicial declaratória de sua propriedade. Se uma parte negocia coisa antes que o juiz lhe atribua a propriedade, deverá, caso seja vencido, entregar à contraparte vencedora outra coisa de valor e preço idênticos aos daquela que vendeu precipitadamente. Aliás, mesmo que o juiz reconheça o seu direito, o vendedor deverá renunciá-lo em favor da outra parte (LV 5,4,21). 


\section{Conclusão}

Em relação à compra e venda descrita no Livro V, Título IV, do Código Visigótico, nota-se um pouco do direito costumeiro, bem como dos direitos helenístico, germânico e, principalmente, romano vulgar. Alguns pontos, entretanto, merecem maior atenção nessa espécie contratual, vista, aqui, à luz do referido Código.

Não pairam dúvidas de que a forma escrita gozava da preferência do Código Visigótico para fins de compra e venda, muito embora esse contrato pudesse ser também celebrado perante testemunhas. Entretanto, mais importante que saber se a prática de documentar atos e negócios jurídicos provinha do direito helenístico ou romano, é reconhecer que a escritura da compra e venda conferia maior segurança a esse contrato amplamente utilizado na época visigoda - e tanto o era que havia cláusula penal para o caso de descumprimento do pactuado por escrito, além de punir-se a falsidade documental e a coação (vedada esta última, inclusive, na celebração verbal perante testemunhas).

A compra e venda aperfeiçoava-se pela escritura lavrada após ou no momento da entrega do preço, assim como pelo preço dado perante testemunhas, gerando, tanto aquela quanto este, o efeito translativo imediato.

A proibição de que a compra e venda recaísse sobre coisa alheia era outra disposição bem elaborada: não somente por afirmar que a coisa, onde quer que esteja ou com quem esteja, pertence ao dono, mas também por ir muito além e reger a situação dos contraentes (comprador e vendedor) e demais envolvidos (legítimo proprietário).

Não poderiam ser vendidas a coisa em litígio e a coisa a ser obtida por decisão judicial, havendo, com o objetivo de conferir maior segurança contratual, a responsabilização dos que delas se dispusessem indevidamente.

As arras visigóticas mostravam-se peculiares e possuíam grande importância e larga utilização na compra e venda: mais do que mero elemento acidental, representavam um elemento essencial, de modo que o legislador descreveu em detalhes as obrigações delas oriundas (principalmente, em face do vendedor) e, inclusive, de maneira congruente com a lex commissoria do direito romano.

A apresentação de fiador pelo vendedor quanto este não demonstrasse ser idôneo (solvente) era condição cujo cumprimento assegurava a entrega da coisa e evitava a negociação incerta (por exemplo, de coisa alheia, futura ou litigiosa), bem como resguardava o comprador do inconveniente de não receber a coisa pela qual pagou. Atentou-se, portanto, para o recíproco e livre consentimento dos contraentes e para a segurança do contrato. 
Não se descartam a influência helenística, o costume tradicional germânico e, sobretudo, a presença do elaborado direito romano (ainda que vulgar), traços variados que só vieram a contribuir para a riqueza da compra e venda descrita no Código Visigótico.

São Paulo, 31 de julho de 2017.

\section{Referências}

AZEVEDO, Luiz Carlos de. O direito visigótico. Revista da Faculdade de Direito da Universidade de São Paulo, São Paulo, v. 96, p. 3-16, jan./dez. 2001.

CÓRCOLES OLAITZ, Edorta. El contrato de compraventa a la luz de las fórmulas visigodas. Revista Internacional de Derecho Romano, Ciudad Real, n. 1, p. 309-330, oct. 2008.

COSTA, Mário Júlio de Almeida. História do direito português. 4. ed. Coimbra: Almedina, 2010.

ESPANHA. Fuero juzgo en latín y castellano: cotejado con los más antiguos y preciosos códices por La Real Academia Española. Madrid: Ibarra, Impresor de Cámara de S. M., 1815.

FERNÁNDEZ ESPINAR, Ramón. La compraventa en el derecho medieval español. Anuario de Historia del Derecho Español (AHDE), Madrid, n. 25, p. 293-528, 1955.

GARCÍA-GALLO DE DIEGO, Alfonso. Consideraciones críticas de los estudios sobre la legislación y la costumbre visigodas. Anuario de Historia del Derecho Español (AHDE), Madrid, n. 44, p. 343-464, 1974.

. Nacionalidad y territorialidad del Derecho en la época visigoda. Anuario de Historia del Derecho Español (AHDE), Madrid, n. 13, p. 168-264, 1936-1941.

HINOJOSA Y NAVEROS, Eduardo de. Historia general del derecho español. Madrid: Tipografía de los Huérfanos, 1887. t. 1.

JUSTO, A. SANTOS. Direito privado romano. 2. ed. Coimbra: Coimbra Editora, 2006. v. 2 (direito das obrigações).

LEVY, Ernst. Derecho romano vulgar de occidente. Derecho de bienes. Introducción y traducción de Ignacio Cremades Ugarte Versión preliminar interna para IRHD por Francisco Ramos Bossini. Philadelphia: American Philosophical Society, 1951.

. Weströmisches Vulgarrecht. Das Obligationenrecht. Weimer: Böhlau, 1956.

MARLASCA MARTÍNEZ, Olga. Los actos jurídicos documentados en los textos legales visigodos. Estudios de Deusto, Bilbao, v. 58, n. 1, p. 79-113, enero/jun. 2010.

MERÊA, Manuel Paulo. Estudos de direito hispânico medieval. Coimbra: Imprensa da Universidade, 1952. v. 1.

. Estudos de direito visigótico. Coimbra: Imprensa da Universidade, 1948. 
MONCADA, L. Cabral de. Estudos de história do direito. Coimbra: Imprensa da Universidade, 1948. v. 1.

ORS. Álvaro d'. Creditum y contractus. Anuario de historia del derecho español, [S.1], n. 26, p. 183-208, 1956.

. La territorialidad del derecho de los visigodos. In: VISMARA, G. et al. Estudios visigóticos. Roma-Madrid: Consejo Superior de Investigaciones Científicas, 1956. v. 1, p. 91-150. (Cuadernos del Instituto Jurídico Español, 5).

OTERO VARELA, Alfonso. Las arras en el Derecho español medieval. Anuario de Historia del Derecho Español (AHDE), Madrid, n. 25, p. 189-210, 1955.

PETIT, Carlos. Fiadores y fianzas en derecho romano visigodo. Sevilla: Universidad de Sevilla, 1983. (Serie Derecho n. 45).

SCHIOPPA, Antonio Padoa. História do direito na Europa: da Idade Média à Idade Contemporânea. São Paulo: WMF Martins Fontes, 2014.

SILVA, Nuno J. Espinosa Gomes da. História do direito português: Fontes do direito. 4. ed. Lisboa: Calouste Gulbenkian, 2006.

ZEUMER, Karl. Historia de la legislación visigoda. Traducción del alemán por Carlos Clavería. Barcelona: Facultad de Derecho de la Universidad de Barcelona, 1944. 
